CZASOPISMO INŻYNIERII LADDOWEJ, ŚRODOWISKA I ARCHITEKTURY JOURNAL OF CIVIL ENGINEERING, ENVIRONMENT AND ARCHITECTURE JCEEA, t. XXXII, z. 62 (3/II/15), lipiec-wrzesień 2015, s. 485-497

Ireneusz WYCZAŁEK ${ }^{1}$

Michal WYCZALEK ${ }^{2}$

Artur PLICHTA ${ }^{3}$

\title{
INVENTORY MEASUREMENTS BASED ON NON- METRIC AERIAL PHOTOS FROM THE BOARD OF UNMANNED AERIAL VEHICLE (UAV)
}

\begin{abstract}
The main task of land surveying, among others, is efficient implementation of the inventory of new objects, what sometimes require doing measurements in difficult terrain (mud, cuttings, moving earth masses, working at high altitude) and during ongoing construction works. Geodetic surveys are primarily used to update some databases essential for Polish principal national map, but they also support cadastral and control measurements related to excavation or construction works. Field surveys are usually done by total station or satellite GNSS receivers in a way that guarantees accuracies required in geodesy. It is also allowed the usage of other methods that ensure required accuracies. Photogrammetric technique is one of those methods. Despite the great precision and many other advantages (overall points collection and archiving the state of the object), it has not found a proper place among field measurement methods. Revolutionary developments in this area occurred along the development of small, unmanned flying vehicles (UAV) which can carry onboard camera or other sensor, and can reach places difficult to access by humans. Development of images obtained this way supports more and more developed computer software.

This paper aims to bring the adopted method of measuring and computing images taken out from the board of hexacopter (6-rotor drone), discussion about obtained precision and presentation the results of the development of a number of selected terrain objects. As a result, the study found that the results obtained in conjunction with the ability to reach inaccessible places and non-invasive measurement allow to consider this method as a viable alternative to direct methods of inventory measurements.
\end{abstract}

Keywords: Aerial mapping, photogrammetry, geodatabases

\footnotetext{
${ }^{1}$ Autor do korespondencji: Ireneusz Wyczałek, Politechnika Poznańska, Instytut Inżynierii Lądowej, 60-965 Poznań, ul. Piotrowo 5, telefon 48616652 420, ireneusz.wyczalek@put.poznan.pl.

${ }^{2}$ Michał Wyczałek, Politechnika Poznańska, Instytut Inżynierii Lądowej, telefon 48616652421 , 60-965 Poznań, ul. Piotrowo 5, michal.wyczalek@put.poznan.pl.

${ }^{3}$ Artur Plichta, Politechnika Poznańska, Instytut Inżynierii Lądowej, telefon 48616652 421, 60-965 Poznań, ul. Piotrowo 5, artur.plichta@put.poznan.pl.
} 


\section{Introduction}

Inventory means - in general terms - the set of operations performed in order to determine the current state of an object or a fragment of space. From geometrical point of view it is a measurement determining the position and shape of one or more objects, or parts of them, associated sometimes with the collection of its selected non-geometrical features. In this context surveyors carry out asbuilt inventory of buildings or structures (roads, towers), and network utilities. The main purpose of inventory measurements in Poland is to update two national databases: EGiB (Registry of Land and Property) and GESUT (Geodetic Registry of Infrastructure Networks), on the base of which is compiled the base map. Currently, it is also required to update the information about general geographic objects, which will be stored in new database called BDOT500.

In practice, the geodetic inventory is performed using direct measurement methods (tacheometry, leveling, GNSS satellite measurements), referenced to the national geodetic control network. After the necessary calculations the set of field data is used to update spatial information systems, a detailed topographic maps and to calculate geometric characteristics (linear dimensions, area, etc.) of measured object. Sometimes it is important to determine levels of land surface or artificial spatial forms, what is often associated with the creation of digital terrain model or other forms of visualization of the third dimension.

Precision of inventory measurements should be relatively high. This necessity lead to ensure adequate precision of equipment in conjunction with preciseness of identification of measured details. In practice, the position of the points defining the object is determined by the average horizontal error, and if the vertical component is also measured, it is usually determined with mean error of height. Such big accuracy can only be obtained by the foregoing geodetic methods or by laser scanning, but - using photogrammetric techniques the application of aerial photography from low-altitude $(30-100 \mathrm{~m})$ is becoming more and more realistic.

Photogrammetric survey requires common elaboration of a block of images overlapping in at least 60 percent (the more the better), that comprise proper determination of orientation elements and further conversion to orthogonal form. The result of this work is 3D model of land cover (DSM), which can be projected onto the plane of the map or vectorised. Low-altitude aerial photogrammetry makes now possible to obtain the model with spatial resolution less than 1 centimeter and accuracy of several centimeters. Supporting sufficiently large coverage and the use of many common points, such accuracy can even be obtained using non-metric cameras. There are currently a number of works on the development of UAS technology (Unmanned Aerial Systems), both the hardware- and software-wise, carried out by research on the automation of flight and collection of images, but also securing drones from collision with the environment, make them more reliable in operation. Also photogrammetric software is being developed to be more efficient, more automatic and precise. 
Inventory measurements based on non-metric aerial photos from the board... 487

The subject of this paper is to present the current state of works - both in terms of international and own research - on the use of low-altitude aerial survey of buildings and other objects whose geometrical features are used to obtain the necessary spatial information. Measurement and calculation procedures are discussed below, their potential precision is evaluated and the selected application solutions are presented. The results of these applications confirm the theoretical possibility of UAS technology in the field of an inventory (or as-build) measurement requirements.

\section{Current state of research on the use of UAS for the purpose of inventory}

Inventory survey of spatial objects using unmanned aviation system needs to make the following necessary works:

- preparation of flying vehicle and on-board photographic equipment,

- designing the flight path and acquisition of photos,

- elaboration of photogrammetric images,

- extraction of the 3D model (from image point cloud) on the base of geometric and radiometric characteristics of pixels in images,

- development of model (orthophotomap, vector model, DTM/DSM).

All of these topics are conducted by intensive scientific research and application works. Due to the large range of literature the topic in the review of this work focuses mainly on publications from 2013, this is the time when similar works were undertaken at the Poznan University of Technology. Unmanned aerial systems (UAS $[5,9,10])$ are called also remotely controlled systems (RPAS $[2,7]$ ), multirotor devices [1, 13] or models of airplanes [5], sometimes limited to a wing only $[2,14]$. The main difference in their use is a different flight path -more flexible in the case of rotor's than wing vehicles. Rotor's also have the option of vertical takeoff and landing, which is of great importance in urban or wooded areas. In principle, these vehicles do not require special preparation for the flight, but there are also produced devices which are mounted before every use [16]. In practice, only a preliminary action before the photogrammetric flight is limited to connection the power (batteries) and establishing the route. At present LiPo (lithium-polymer) cells are used as a power source, because they have high capacity at low weight, and low sensitivity to frequent charging and discharging. LiPo package weighing about $1 \mathrm{~kg}$ has a capacity of 10-12k Ah what is enough for 15 to 30 minutes of the flight - depending on construction of a drone, its load and atmospheric conditions.

Currently, the most common sensor for acquiring images of UAV cameras are characterized by a hybrid type properties of 'SLR' and the size of 'compact camera'. In practice the most commonly used cameras are Sony Nex series (5-7) $[2,11,12,18]$. There are used also other cameras recording in 'cropped-frame' CMOS technology (APS-C format). An alternative, due to the different way 
of building a sensor is Foveon, which in one cycle can acquire all color components, what eliminates many drawbacks of CMOS solutions in DSLR cameras [10]. Interesting for the purpose of remote sensing would be recording in near infrared band, however CMOS sensors typically do not provide such a possibility - short waves are optically filtered in the way to sensor. It is possible to take off photo filter, but there is a problem of less sensitivity of CMOS to long waves, and in addition - necessary is to do radiometric calibration of images obtained this way. Bachmann et al. [1] suggest their own solution in this regard, but it is still in the phase of development.

The non-metric camera should be geometrically calibrated, however Greiwe et al. [12], and a number of other UAV users, including the authors of this paper, have noted that the errors in this type of image elaborations have no significant impact on the obtained accuracy - greater effect gives photogrammetric software, mainly aerial triangulation algorithm [15]. Sieberth et al. [20] drew furthermore attention, to a significant impact in the case of frequent drone blur images on the accuracy of matching, and later results of elaborations. The authors proposed their own self-correction algorithm, but Greiwe et al. [10] argue that sharper images provide cameras with Foveon sensor. Cameras that are not built permanently into the structure of drone, are suspended by stabilizing module (preferably 2- or 3-axial gimbal), what allows to control the orientation of the camera, but also reduces the blur of images. In this context, Chabok [6] propose the 3-step sharpening procedure, that combines sensor calibration, camera stabilization of the suspension and the algorithm of reducing residual blur images. The author stated that these actions should significantly increase the accuracy of resulting photogrammetric products.

Flight preparation of drone involves the determination of the route and altitude (what can be done using the program e-mo-tion [14] or similar) as well as directing the camera and setting the shutter on and off. The route is done via the power system under the control of the drone position sensor (GPS) optionally assisted by the INS with gyroscope, accelerometers and onboard computer [8]. The readings of these devices are stored and later (in a greater or lesser extent) are used in the calculation, however Ruiz et al. [17] noticed, that relatively heavy and expensive RTK sensors do not give sufficiently accurate results. According to the authors no worse effect is obtained by calculating the EO (i.e. external orientation parameters) in postprocessing mode, using only matching procedure and a few control points. However, these sensor readings are essential in precision of flight control. Numerous efforts are taken in this field. Among other things, Bender et al. [4] pointed out the benefits of INS, Tsai et al. [21] have developed an algorithm that uses GPS readings along with the INS (called by authors Positioning and Orientation System: POS), Eling et al. [8] made use of all possible sensors, including additional cameras, and Bäumker et al. [3] have considered the use of dual-frequency GNSS receiver (Topcon B110) and flight tracking using a motorized total station (with two headlights 
Inventory measurements based on non-metric aerial photos from the board... 489

on board the drone). Current flight control is designed to help remote control of air vehicles, in particular, ensuring the safety of the flight (both the drone and objects) along the route of its flight. For the purpose of rapid detection of obstacles Holz et al. [13] tested their rotor 2D scanner, two pairs of webcams and ultrasound ring distance detectors in order to develop a fully autonomous flying of UAV. To reach similar result Schneider et al. [19] have used four fisheye type cameras and develop technique to detect obstacles based on the identified distant points.Pictures taken from the UAV can be developed using conventional photogrammetric software, however scientists who tested possible applications of photos from the low altitude noticed that AgiSoft PhotoScan gives much better results in comparison with other programs such as ERDAS LPS, Pix4UAV or Match-AT Pro. This program works almost fully autonomously, using 'coarse-to-fine' strategy in such a way that at first it selects relatively big number of common points in images and on the base of them calculate camera orientation elements, then clarifies the fit of image pixels forming dense point cloud (DSM) and finally performs adjustment of orientation parameters. As a result, almost in real-time the strict parameters of the aerial triangulation and 3D terrain model are determined. On the base of it the orthophotomap can be obtained. Among others, authors of [2] and [15] expressed their satisfaction from the program implemented in a number of diverse testing applications. Using this software user without photogrammetric practice may obtain accurate products with the accuracy of 0.3 pixel. This also have been confirmed by experiments of Fallavollita et al. [9] who successfully used it to archaeological studies. Developing applications using Orthophoto PhotoScan, however, has its Achilles' heel in the case of uneven terrain altitude coverage, among others, in built-up areas.

\section{Tests of photo sensor and software}

\subsection{Elements of interior orientation of the camera Sony Nex-5}

Camera Sony Nex-5 has been selected at Poznan University of Technology as the standard for photographic registration, what is similar to solutions described in most publications cited herein. The camera was initially calibrated at the 'PP test field' (Fig. 1). The first step of the test was determination the elements of internal orientation of the camera and checking of the error vectors (distortion). Targets were installed in two vertical planes containing 40 Control Points (CP) and 20 Independent Check Points (ICP) on each of them, which were photographed several times without changing the standard settings (shooting distance, exposition and aperture). 


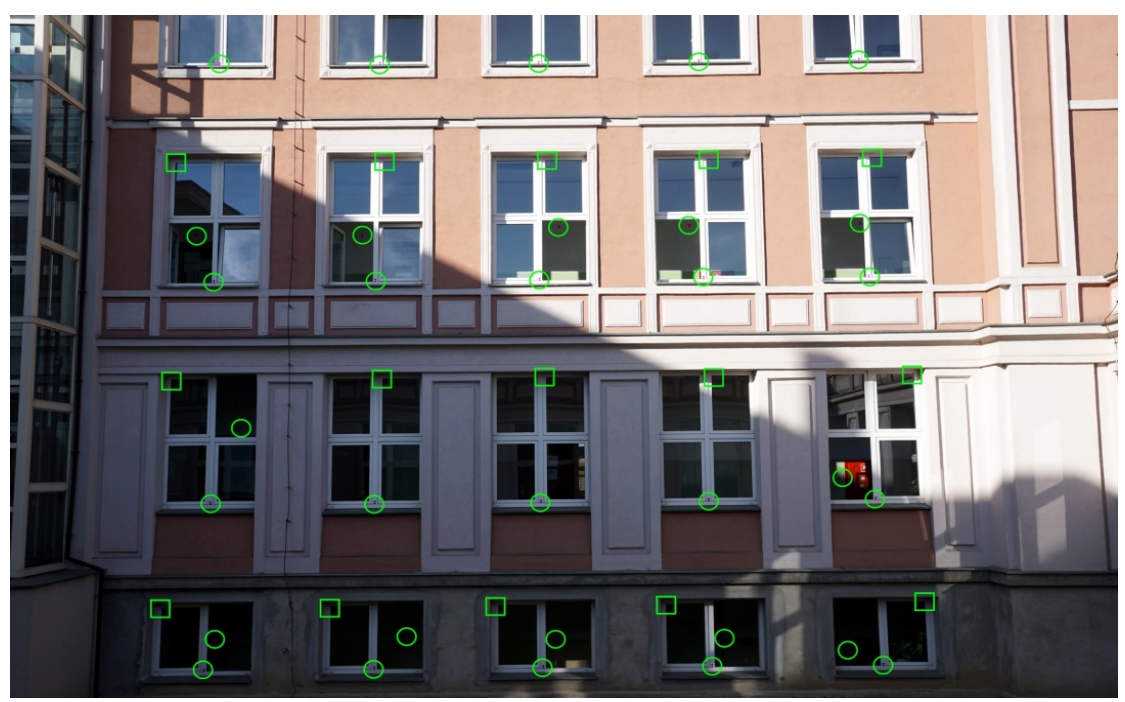

Fig. 1. One of the set of images taken for calibration and testing camera Sony Nex 5 in two-plane 'PP test field' containing: 40 control points (CP) and 20 independent check points ( ICP) measured using precision total station Leica Geosystems TCRP 1201+

Rys. 1. Jeden z obrazów wykonanych w celu kalibracji i testowania kamery SonyNex5 na dwupłaszczyznowym polu testowym PP obejmującym 40 fotopunktów i 20 punktów kontrolowanych mierzonych przy użyciu precyzyjnego tachimetru Leica Geosystems TCRP 1201+

For calibration was used known photogrammetric algorithm for selfcalibration, described by following formula:

$$
\begin{aligned}
& x_{i, j}+w_{i, j}=x_{0}-K_{i} \frac{X_{l}-X_{g}}{Z_{i}-Z_{g}}+x\left(R_{1} T^{2}+k_{z} T^{4}+k_{\mathrm{z}} T^{4}\right)+\left(2 p_{1} y+p_{2}\left(r^{2}+2 x^{2}\right)\right)
\end{aligned}
$$

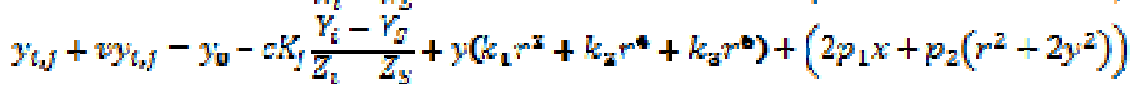

for $i$-th point in $j$-th image of test field, where: $x_{i}, y_{i}$ are image coordinates and $X_{i}, Y_{i}, Z_{i}$ external coordinates of $i$-th point, $x_{0}, y_{0}, c K_{j}, k_{1}, k_{2}, k_{3}, p_{l}$ and $p_{2}$ are elements of internal orientation and $X_{S j}, Y_{S j}, Z_{S j}$ - external orientation of the $j$-th position of the camera.

After several tests it was considered that achieved data are sufficient to the practical use and meet the expected requirements of precision.

\subsection{Camera parameters on the base of photos from ground stations}

Images taken by this camera was used as a source for tests using the abovementioned program AgiSoft PhotoScan. The tests include the alignment of images (matching), creation a points cloud, and conversion to the orthogonal projection. In order to assess the accuracy of the established 3D model selected characteristic points of the wall (Fig. 1) were measured by Leica TCRP 1201+ electronic total station (RMSE $\pm 0,002 \mathrm{~m}$ ) and obtained coordinates were 
compared with homologous locations identified on the model. The results are shown in Table 1. For the latter, displacement vectors between the two measuring techniques are also indicated. These results satisfy both in terms of quality of the model and its accuracy defined in the measured points.

Table 1. Results of camera Sony Nex5 post-calibration test (plane coordinates)

Tabela 1. Wyniki przeprowadzonego testu po kalibracji kamery Sony Nex5 (współrzędne płaskie)

\begin{tabular}{|l|l|r|r|r|r|}
\hline $\mathrm{m}_{\mathrm{x}}(\mathrm{CP})$ & $\mathrm{m}_{\mathrm{y}(\mathrm{CP})}$ & $\min _{\mathrm{x}(\mathrm{ICP})}$ & $\min _{\mathrm{y}(\mathrm{ICP})}$ & $\max _{\mathrm{x}(\mathrm{ICP})}$ & $\max _{\mathrm{y}(\mathrm{ICP})}$ \\
\hline $\pm 0,019 \mathrm{~m}$ & $\pm 0,012 \mathrm{~m}$ & $0,002 \mathrm{~m}$ & $0,003 \mathrm{~m}$ & $0,031 \mathrm{~m}$ & $0,017 \mathrm{~m}$ \\
\hline
\end{tabular}

\subsection{Inventory of the railway embankment}

Practically the program PhotoScan was tested for development of high escarpment along the railway track in the trench. Ninety one pictures were taken from the opposite slope in three horizontal lines - bottom, middle and top. Exposure settings: distance $30-45 \mathrm{~m}$, aperture 8,0 , focal length $40 \mathrm{~mm}$ (for $3,5 "$ ), exposure time $1 / 60 \mathrm{sec}$. Checkpoints were selected on poles of the traction by measuring their position with RTS Leica TCRP 1201+ (RMSE $\pm 0.005 \mathrm{~m})$. Model development of the slope covered a set of common steps: 1) matching images and creating points cloud, 2) fitting the control points, 3) creating a 3D TIN model. Figure 2 shows the developed point cloud (left) and 3D model of local landslide (right), which clearly sketched spatial shape.

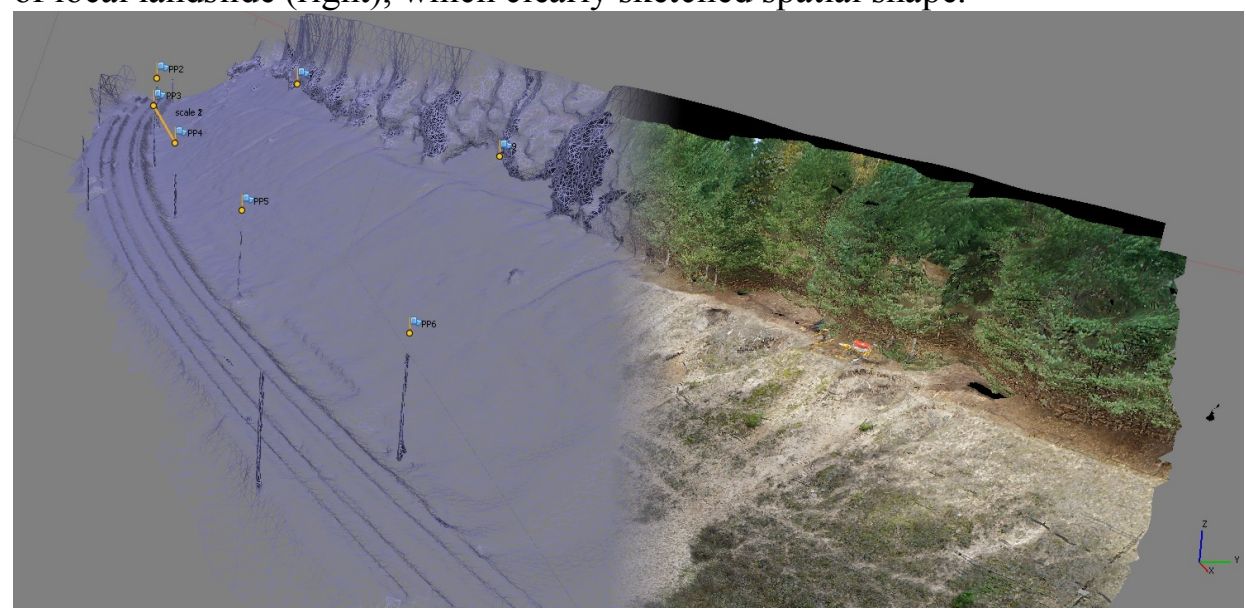

Fig. 2. The 3D model of escarpment developed using the program AgiSoft PhotoScan Professional on the base of a set of 91 images (with the fragment of orthorectified image)

Rys. 2. Trójwymiarowy model skarpy opracowany w programie AgiSoft PhotoScan Professional na podstawie zestawu 91 zdjęć ( $\mathrm{z}$ fragmentem wpasowanego obrazu fotograficznego)

In the table 2 the results obtained from comparison of the group of ICP between photo model and 3D laser scan (using Leica C10). 
Table 2. Comparison of coordinates of points collected in 3D model and the laser point cloud

Tabela 2. Porównanie współrzędnych punktów odczytanych na modelu 3D z ich odpowiednikami z chmury punktów laserowych (współrzędne zdjęcia).

\begin{tabular}{|l|l|r|r|r|r|}
\hline $\mathrm{m}_{\mathrm{x}(\mathrm{CP})}$ & $\mathrm{m}_{\mathrm{y}(\mathrm{CP})}$ & $\min _{\mathrm{x}(\mathrm{ICP})}$ & $\min _{\mathrm{y}(\mathrm{ICP})}$ & $\max _{\mathrm{x}(\mathrm{ICP})}$ & $\max _{\mathrm{y}(\mathrm{ICP})}$ \\
\hline $\pm 0,035 \mathrm{~m}$ & $\pm 0,042 \mathrm{~m}$ & $0,007 \mathrm{~m}$ & $0,012 \mathrm{~m}$ & $0,062 \mathrm{~m}$ & $0,067 \mathrm{~m}$ \\
\hline
\end{tabular}

Inventory of the escarpment was used to perform geotechnical expertise, and on its basis, on its basis was developed design of its strengthening and modernization.

\section{Applications of UAS in geodetic survey}

Attempts with the use of UAVs at Poznan University of Technology are conducted in the geodetic inventory for large-scale mapping (updating national geodatabases EGiB, GESUT and BDOT500 and basic map), terrain modeling and volume calculation of the masses of soil or aggregate. As a supporting device we use a 6-rotor drone made on the base of MikroKopter components, and since 2014 also drone on components of DJI company. They have personally created carbon frame and 2-axial gimbal. The drones have payload up to about $2 \mathrm{~kg}$, the height flight to about $250 \mathrm{~m}$ above the ground, maximum speed $15 \mathrm{~m} / \mathrm{s}$ and time of fly to 15-20 minutes. The devices are positioned by GPS and INS sensors, their flight is controlled using the applications provided by their manufacturers. As the sensor for purposes presented here was used the same camera Sony Nex-5 with standard lens Sony SEL1588 (18-55 mm). Series of images obtained during the flight were processed using AgiSoft PhotoScan in automatic mode. Participation of the operator consists of uploading and identifying control GCP-s, and 'cleaning' the resulting cloud of points prior to further processing.

\subsection{Updating databases BDOT500 to comply maps for design purposes}

Under the current Polish regulations [15] the national principal map is currently performed on the base of six geodatabases, of which three: EGiB, GESUT and BDOT500 include data concerning terrain or underground objects. The first two bases have been conducted for a long time and are largely complete and up-to-date, the base BDOT500 is a new product and does not contain too much data; mostly it is necessary to fill it from the beginning. BDOT500 contains basically data about all terrain objects not stored in the databases EGiB and GESUT.

An attempt to collect BDOT500 objects was taken in making the map of Daszewice near Poznan. Databases of a part of that site were taken from Poznań District Governor's Office and updated on the base of geodetic survey. Pictures of this ares were collected from the UAV flying $40 \mathrm{~m}$ over the ground and 3D model was developed based on three GCPs lying in the central part 
of the block. As we noticed in [15] that it was very good example of getting precise and reliable information about components of BDOT500 database. Differences between the map and identified location of selected places do not generally exceed $4-5 \mathrm{~cm}$.

Table 3. Summary of results of measurement terrain objects of DBOT500 geodatabase in the 3D model elaborated from UAV images

Tabela 3. Zestawienie wyników pomiaru szczegółów terenowych gromadzonych w geodezyjnej bazie danych BDOT500 w oparciu o model 3D opracowany ze zdjęć z pokładu UAV

\begin{tabular}{|l|l|r|r|r|r|}
\hline $\mathrm{m}_{\mathrm{x}(\mathrm{CP})}$ & $\mathrm{m}_{\mathrm{y}(\mathrm{CP})}$ & $\min _{\mathrm{x}(\mathrm{ICP})}$ & $\min _{\mathrm{y}(\mathrm{ICP})}$ & $\max _{\mathrm{x}(\mathrm{ICP})}$ & $\max _{\mathrm{y}(\mathrm{ICP})}$ \\
\hline $\pm 0,026 \mathrm{~m}$ & $\pm 0,029 \mathrm{~m}$ & $0,008 \mathrm{~m}$ & $0,006 \mathrm{~m}$ & $0,044 \mathrm{~m}$ & $0,047 \mathrm{~m}$ \\
\hline
\end{tabular}

\subsection{The inventory of a parish cemetery}

One of the modern forms of administration of cemeteries is thematic spatial information system. It includes more or less accurate map of the area of the cemetery and associated database of the buried people. Sometimes this area is imaged on the orthophotomap, and individual graves are documented in the pictures. In order to perform accurate graphic documentation of graveyard in Michorzewo the block of UAV photographs (from $50 \mathrm{~m}$ ) has been developed. Two attempts were taken to register the graveyard, each of them referred to separately declared GCPs (marked or identified). Their position was measured by GPS/RTN with a typical accuracy $\pm 0,03 \mathrm{~m}$. The accuracy of spatial elaboration of images was performed by comparing the results of both studies. In comparison 20 clearly identifiable points, we obtained accuracy described by mean squared error $R M S E= \pm 0,055 \mathrm{~m}$.

\subsection{The inventory of the Botanical Garden}

Botanical Garden in Poznań covers the area of dozens of acres, and its individual parts are living illustration of fauna growing at different vegetation zones. To ensure adequate conditions of plant growth in combination with aesthetic effects, in particular fragments of a garden much varied shape is made. For this reason, the photogrammetric development from the low altitude seems to be one of the most effective methods of inventory of objects making the structure of the garden. Some part of the garden had been measured twice once in the final phase of winter hibernation, the second one in the Spring, during the growth of the earliest species of plants. In each case, reference was made to the same six ground control points (GCP) and was inspected in 10 independent check points (ICP), all measured using GNSS/RTN satellite technique. Images on Fig. 3 shows respectively:

a) the area after elaboration, with control points and check points,

b) differences in fitting orthoimages in four natural details used as ICP-s. 
It was reached similar accuracy parameters, as in the case of cemetery in Michorzewo. For special attention deserves the visual effect of the resulting studies, mainly for the case of the spring. The figure 4 shows the composition of orthophotomap created by the juxtaposition of two pieces of the same area, but taken at different stages of plant growth. The attention attracts a surprisingly large compliance in the continuity of the composite image from two independent elaborations.

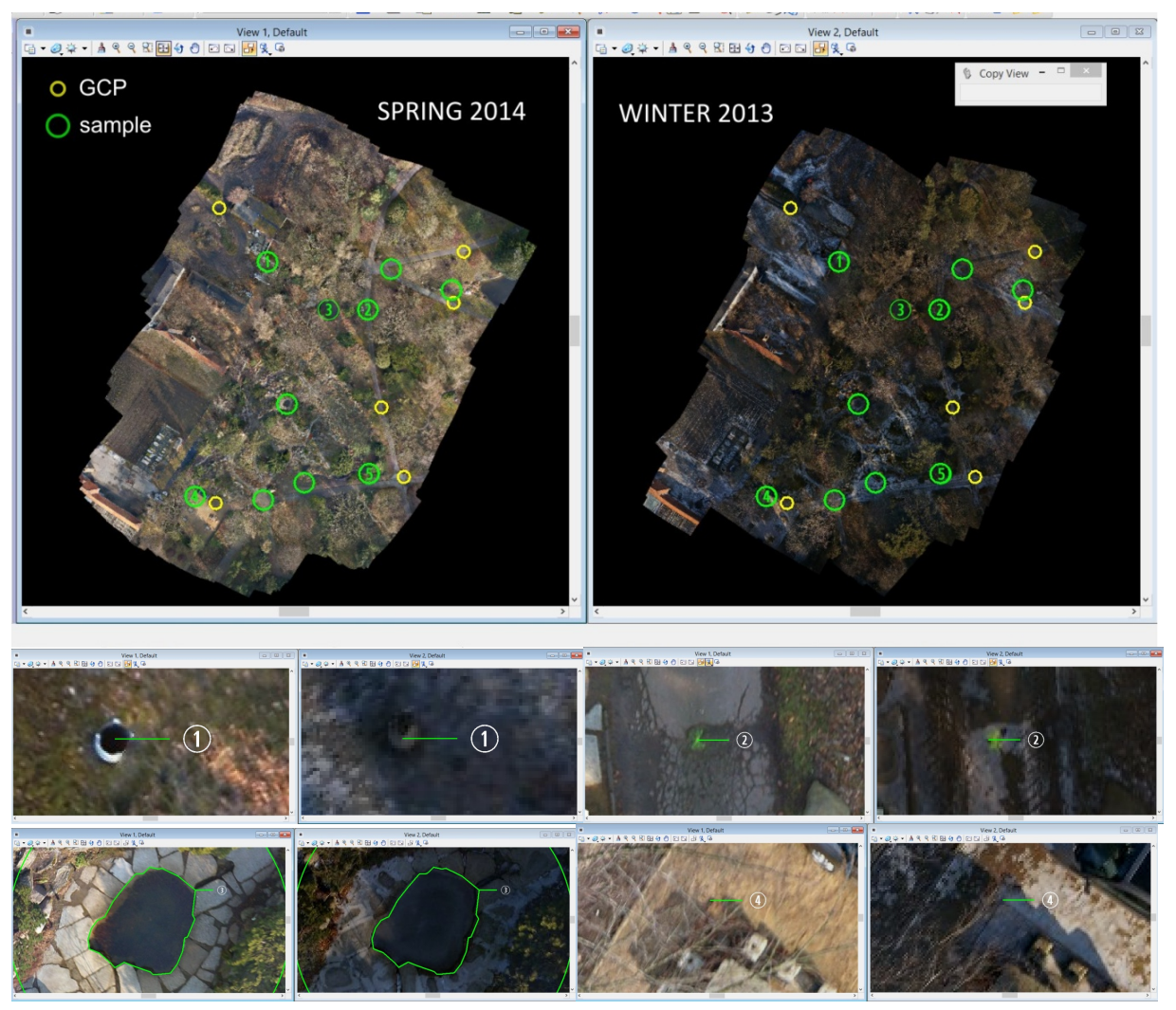

Fig. 3. Details of elaboration of a part of Botanical Garden in Poznan: (top) the range and final orthophotomap from two sessions, (down) differences between projections at several ICP-s

Rys. 3. Szczegóły opracowania części Ogrodu Botanicznego w Poznaniu: (góra) zakres i końcowa ortofotomapa z dwóch sesji oraz (dół) różnice między odwzorowaniami kilku punktów 


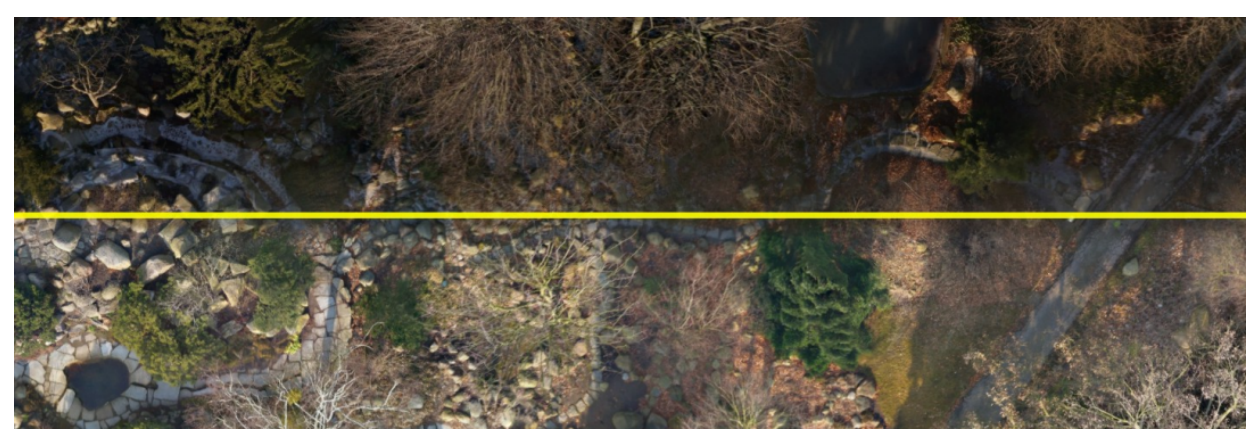

Fig. 4. Comparison (view) of independent elaboration of orthophotomap from two sessions

Rys. 4. Porównanie (widok) niezależnego opracowania ortofotomapy z dwóch sesji pomiarowych

\section{Conclusions and future works}

UAS are tested and implemented by an increasing number of geodesic companies [2] and national mapping agencies [7]. It is recognized, however, at this stage of technology they do not meet expected requirements, mainly from the point of view of their service, but they can be used as a valuable addition to the other techniques [7]. The work undertaken at Poznan University of Technology [15] shows that this technique has several advantages that go beyond the capabilities of a typical measurement for map production. They can therefore be used in measuring small objects (safely in areas up to $400 \times 400 \mathrm{~m}$ ). The technology described in this publication, as well as wide range of its applications, shows that photogrammetry based on non-metric images from UAVs can be successfully used in inventory measurements. However, the technique has also its drawbacks, among other area restrictions (must be visible by the drone operator) and the potential risk to people and property in the event of failure of the drone. This aspect of the studies requires special attention and needs to develop methods, maybe some terms of legislation, to ensure the safe photographic registration of measured area.

Subsequently, the surveying team at Poznan University of Technology plan to improve the quality of studies by: (a) implementation of the principles of flight safety, (b) the development own techniques to elaborate photos.

\section{Bibliography}

[1] Bachmann F., Herbst R., Gebbers R., Hafner V.V.: Micro UAV based georeferenced orthophoto generation in VIS + NIR for precision agriculture. ISPRS Archives, Vol. XL-1/W2, Ed.: G. Grenzdörffer and R. Bill, 2013, 11-16.

[2] Barry P., Coakley R.: Field accuracy test of RPAS photogrammetry. ISPRS Archives, Vol. XL-1/W2, Ed.: G. Grenzdörffer and R. Bill, 2013, 27-31. 
[3] Bäumker M., Przybilla H.-J., Zurhorst A.: Enhancements in UAV flight control and sensor orientation. ISPRS Archives, Vol. XL-1/W2, Ed.: G. Grenzdörffer and R. Bill, 2013, 33-38.

[4] Bender D., Schikora M., Sturm J., Cremers D.: A graph based bundle adjustment for INS-camera calibration. ISPRS Archives, Vol. XL-1/W2, Ed.: G. Grenzdörffer and R. Bill, 2013, 39-44.

[5] Buettner A., Roeser H.P.: Hyperspectral remote sensing with the UAS "Stuttgarter Adler" - challenges, experiences and first results. ISPRS Archives, Vol. XL-1/W2, Ed.: G. Grenzdörffer and R. Bill, 2013, 61-65.

[6] Chabok M.: Eliminating and modelling non-metric camera sensor distortions caused by sidewise and forward motion of the UAV. ISPRS Archives, Vol. XL-1/W2, Ed.: G. Grenzdörffer and R. Bill, 2013, 73-79.

[7] Cramer M., Bovet S., Gültlinger M., Honkavaara E., McGill A., Rijsdijk M., Tabor M., Tournadre V.: On the use of RPAS in national mapping - the EuroSDR point of view. ISPRS Archives, Vol. XL-1/W2, Ed.: G. Grenzdörffer and R. Bill, 2013, 93-99.

[8] Eling C., Klingbeil L., Wieland M., Kuhlmann H.: A precise position and attitude determination system for lightweight unmanned aerial vehicles. ISPRS Archives, Vol. XL-1/W2, Ed.: G. Grenzdörffer and R. Bill, 2013, 113-118.

[9] Fallavollita P., Balsi M., Esposito S., Melis M. G., Milanese M., Zappino L.: UAS for archaeology - new perspectives on aerial documentation. ISPRS Archives, Vol. XL-1/W2, Ed.: G. Grenzdörffer and R. Bill, 2013, 131-135.

[10] Greiwe A., Gehrke R., Spreckels V., Schlienkamp A.: Aspects of DEM generation from UAS imagery. ISPRS Archives, Vol. XL-1/W2, Ed.: G. Grenzdörffer and R. Bill, 2013, 163-167.

[11] Grenzdörffer G.J.: UAS-based automatic bird count of a common gull colony. ISPRS Archives, Vol. XL-1/W2, Ed.: G. Grenzdörffer and R. Bill, 2013, 169-174.

[12] Gruen A., Huang X., Qin R., Du T., Fang W., Boavida J., Oliveira A.: Joint processing of UAV imagery and terrestrial mobile mapping system data for very high resolution city modeling. ISPRS Archives, Vol. XL-1/W2, Ed.: G. Grenzdörffer and R. Bill, 2013, 175-182.

[13] Holz D., Nieuwenhuisen M., Droeschel D., Schreiber M., Behnke S.: Towards multimodal omnidirectional obstacle detection for autonomous unmanned aerial vehicles. ISPRS Archives, Vol. XL-1/W2, Ed.: G. Grenzdörffer and R. Bill, 2013, 201-206.

[14] Küng O., Strecha C., Beyeler A., Zufferey J-C., Floreano D., Fua P., Gervaix F., 2011, The accuracy of automatic photogrammetric techniques on ultra-light UAV imagery. Int. Archives of the Photogrammetry, Remote Sensing and Spatial Information Sciences, Vol. XXXVIII-1/C22.

[15] Plichta A., Wyczałek I., Wyczałek M., Mapy do celów projektowych w świetle nowych uwarunkowań prawnych oraz technicznych tworzenia mapy zasadniczej, „Geodezyjne systemy pomiarowe dla budownictwa”, Wyd. PW, Warszawa 2014.

[16] Novadem, 2013: http://www.novadem.com/Produits_NX110m-en.html (available 30.12.2013).

[17] Ruiz J.J., Diaz-Mas L., Perez F., Viguria A.: Evaluating the accuracy of DEM generation algorithms from UAV imagery. ISPRS Archives, Vol. XL-1/W2,

Ed.: G. Grenzdörffer and R. Bill, 2013, 333-337. 
Inventory measurements based on non-metric aerial photos from the board... 497

[18] Ruzgiene B., Aksamitauskas C.: The use of UAV systems for mapping of built-up area. ISPRS Archives, Vol. XL-1/W2, Ed.: G. Grenzdörffer and R. Bill, 2013, 349-353.

[19] Schneider J., Läbe T., Förstner W.: Incremental real-time bundle adjustment for multi-camera systems with points at infinity. ISPRS Archives, Vol. XL-1/W2, Ed.: G. Grenzdörffer and R. Bill, 2013, 355-360.

[20] Sieberth T., Wackrow R., Chandler J.H.: Automatic isolation of blurred images from UAV image sequences. ISPRS Archives, Vol. XL-1/W2, Ed.: G. Grenzdörffer and R. Bill, 2013, 361-366.

[21] Tsai M.L., Chiang K.W., Lo C.F., Ch C.H.: The performance analysis of a UAV based mobile mapping system platform. ISPRS Archives, Vol. XL-1/W2,

Ed.: G. Grenzdörffer and R. Bill, 2013, 407-411.

\section{POMIARY INWENTARYZACYJNE W OPARCIU O NIEMETRYCZNE ZDJECIA LOTNICZE Z POKŁADU BEZZALOGOWEGO POJAZDU LATAJĄCEGO (UAV)}

\section{Streszczenie}

Do zadań geodezji wynikających z zapisów prawa budowlanego należy między innymi sprawne wykonanie inwentaryzacji nowopowstających obiektów, wymagające niekiedy pomiaru w trudnych warunkach terenowych (błoto, wykopy, przemieszczane masy ziemne, praca na znacznej wysokości) i podczas realizacji prac budowlanych. Pomiary inwentaryzacyjne służą przede wszystkim do aktualizacji niektórych baz danych zasilających mapę zasadniczą, wspomagają inne bazy danych tematycznych, ale mają też cel ewidencyjno-kontrolny odnośnie do wykonanych prac ziemnych lub postępu robót budowlanych.

Pomiary terenowe wykonuje się zwykle metodą tachimetryczną lub satelitarną GNSS w taki sposób, aby osiągnąć dokładności spełniające standardy robót geodezyjnych. Dopuszcza się też zastosowanie innych metod pomiarowych zapewniających uzyskanie wymaganych dokładności. Technika fotogrametryczna jest jedną z takich metod. Mimo znacznych możliwości dokładnościowych i wielu innych zalet (całościowa rejestracja i archiwizacja stanu obiektu), nie znalazła ona jednak stałego miejsca w szczegółowych pomiarach terenowych. Rewolucyjne zmiany w tej dziedzinie nastąpiły wraz z rozwojem niewielkich, bezzałogowych obiektów latających (UAV), które mogą przenosić na pokładzie kamerę (aparat) lub inny sensor i docierać w miejsca trudne do dostępu przez człowieka. Opracowaniu zdjęć uzyskanych tym sposobem służy coraz bardziej rozwinięte oprogramowanie komputerowe.

Niniejsza praca ma na celu przybliżenie przyjętej metody pomiarowo-obliczeniowej z użyciem zdjęć z heksakoptera (6-wirnikowego drona), omówienie wykonanych testów dokładnościowych i przedstawienie wyników opracowania kilku wybranych obiektów terenowych. W efekcie przeprowadzonych badań stwierdzono, że uzyskane wyniki w powiązaniu z możliwością dotarcia do niedostępnych miejsc i bezinwazyjnego pomiaru pozwalają uznać tę metodę jako realną alternatywę dla bezpośrednich metod pomiaru inwentaryzacyjnego.

Słowa kluczowe: kartografia lotnicza, fotogrametria, bazy danych geodezyjnych

Przestano do redakcji:30.05.2015

Przyjęto do druku:1.12.2015

DOI: $10.7862 / \mathrm{rb} .2015 .170$ 